\title{
透明ゴム製品中の亞鉛の・定量
}

\section{Edmondo Casazza}

Gcmma (Millaro), 1939, 3, 65

R. Chem. Tech, 1940, 13, 181

大杉友、七譯

こンに記載したカ法は透明ゴム製品中に酸化亞釦又は亞鉛臂颣の形で存在する亞鉛の定最に最も適切な方法 である。此の㮔のゴムは不唀明ゴムに比較して亞釦の含有量が非常に少く最低限度は僅かに $0.05 \%$ に過ぎず 普通含有量の約 $1 / 100$ に及代ない。

此の樣な極端に僅かより含まれて居ない場合には亞鉆の含有量を測定する事が一般法では極めて困難であ

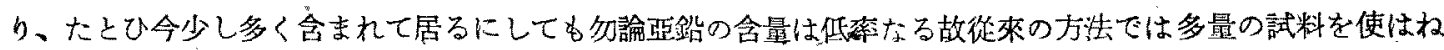
ばならず而むその結果たるゃ壁々正確を期し難い。

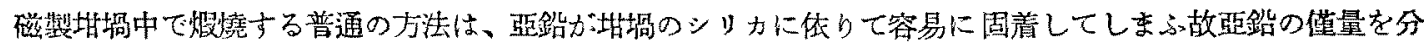

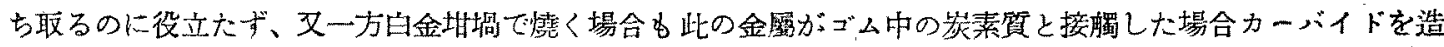
る候向ある䉆遏當でない。

下記分析法の新奇な特徵はゴム中にある無機質の溶液を得るための手段にある。之はゴムを濃硫酸で分解 し、次に有譏質殘椬を隂硝酸で酸化する。

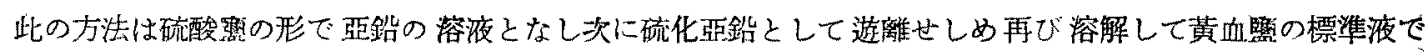
视澱さす既知方法に依り容量測定を行ふのである。

ゴム中にある嚾量の亞銷に對し此の手段に依り正確な結果を與へる篇の最も適切な濃度、酸度及㴧度を泆定 した。

宽驗法

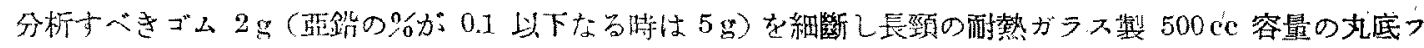

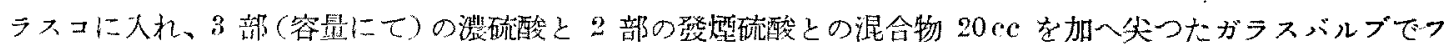

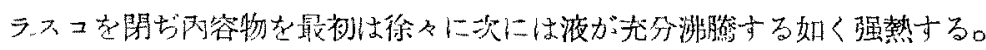

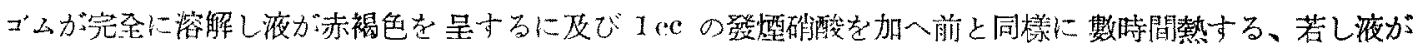
清浚てなく几冷却に際し無色でなければ(ゴムが配合成分を含んで居ると溶液は濁つて着色し或は不溶解性の

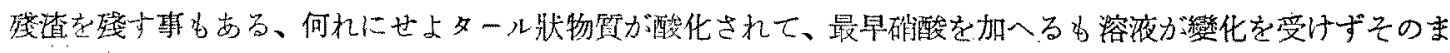

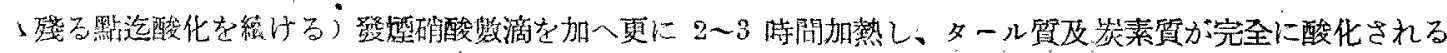

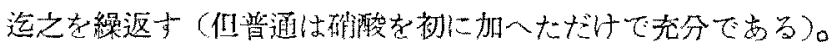

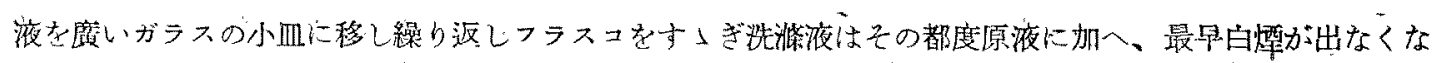

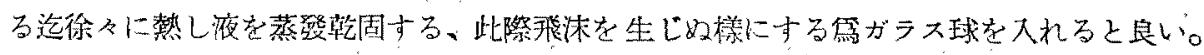

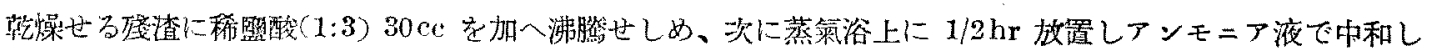
$70 \sim 80^{\circ} \mathrm{C}$ に加熱し渦剩のアンモニア液を加へ(約 5 ce) 涨點に到らしめ、再び蒸氣浴上に $1 / 2 \mathrm{hr}$ 放置後（ピ

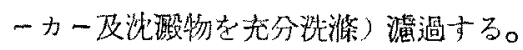




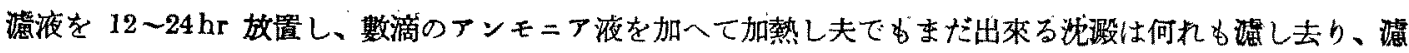
液からら過剩のアンモニアを放逐する䉆に $250 \mathrm{cc}$ のビーカーに入れ $5 \mathrm{~min}$ 間沸腾さす（最早沈澱は生じてはな

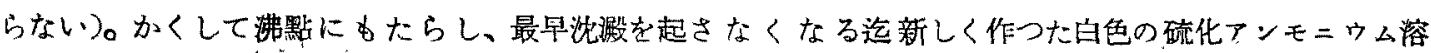

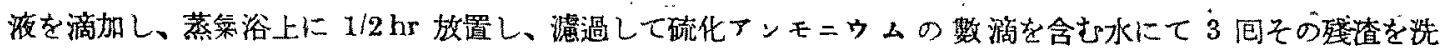
j.o

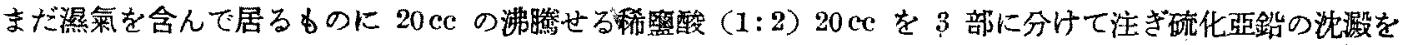

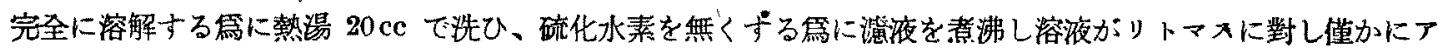

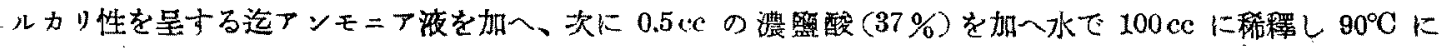
加熱与る。

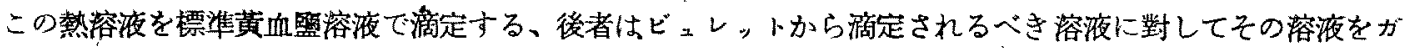

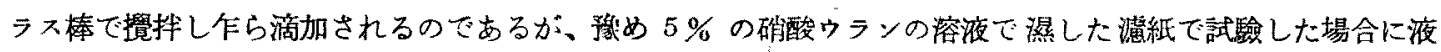

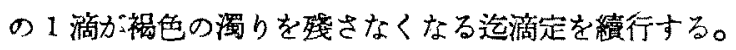

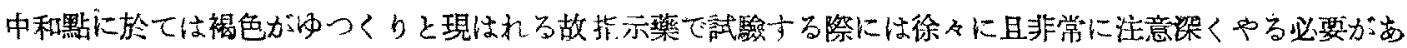

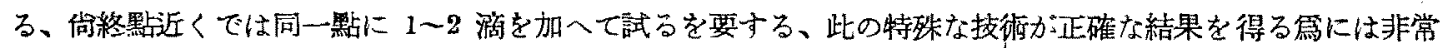
に㻎要である。

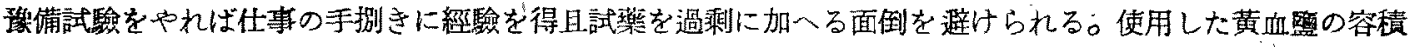

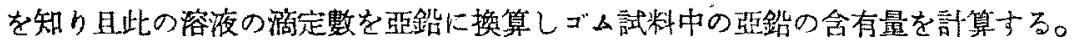

$$
\text { 亞鈖 } \%=\frac{(a-b) T}{P} \times 100
$$

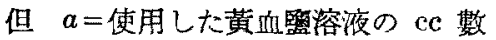

$b=$ 同一條件の下に室白試驗として使用した黄血監溶液の cc 數

$T=$ 黄血䝂溶液の箅定量

$P=$ ゴム試料の g 數

\section{黄血婹溶液の調}

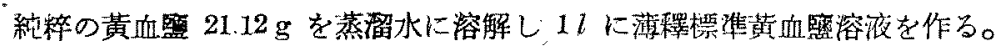

\section{黄血蹈浴波中の亞鉛す滴定}

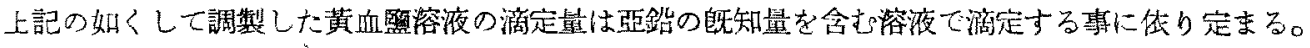

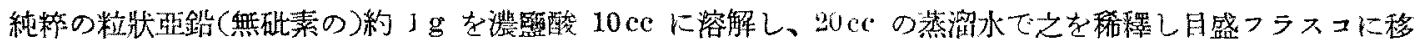

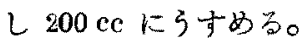

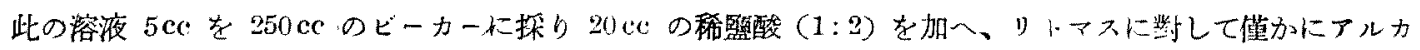

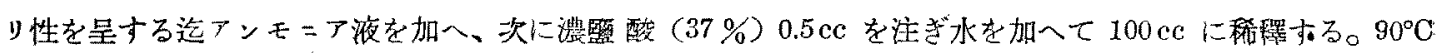
に熱し $5 \%$ の硝酸ウラン溶液を指示藥として標準黃血嚂溶液で激定する、更に同一の方法を上記のゴム中に

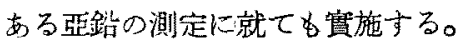

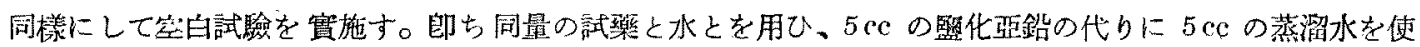

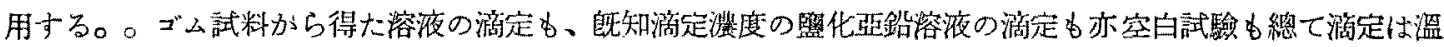

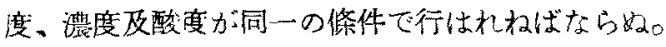

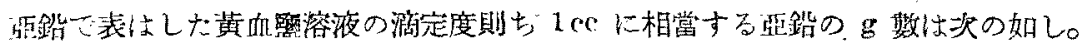




$$
T=\frac{P}{40(A-B)}
$$

但 $P=$ 使用した亞鉆の! 名 数

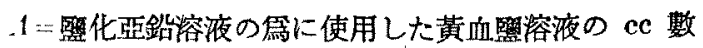

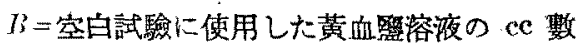

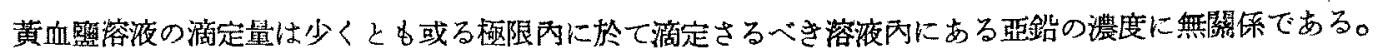

次表は $200 \mathrm{cc}$ 中に亞鍴の $1.0224 \mathrm{~g}$ を含む溶液 $5 \mathrm{cc} 、 2.5 \mathrm{cc}$ 及 $1 \mathrm{cc}$ 並に何も含まないものに就て實驗した 測定の結果走す 。

盟化亞鉊溶液の $\mathrm{ec}$

5.0

2.5

1.0

$0 . \dot{5}$

0.0
韭鉛 $\mathrm{g}$

0.02556

0.01278

0.00511

0.00255

0.0

黄血變溶液の $\mathrm{ce}$
$\mathrm{A}$
5.45
2.85
1.30
0.75
0.25

0.25

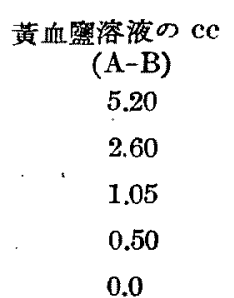

0.0
ゴム中の亞鉛\%

1.278

0.639

0.255

0.127

0.0

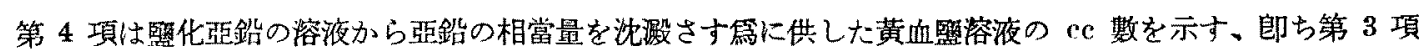
の值から室白試驗に於ける值を減じたものである、但し空白試驗の此の值は第 3 項の最後の值である。

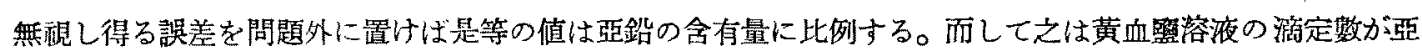
鉛の種々の量に對して夫々一定である事を證する。

此の事望は亞錕含有量の異なるゴム慗品に於て亞鉛の百分率を決定する上に特に重要でるる。

第 5 項はゴム配合物中に存在する亞踏の\%を(此の試驗では $2 \mathrm{~g}$ の試料を取つたものとして)標準黄血照溶 液の相當量の消費を基整として示したものである。ゴム配合物中の亞鋯の\%が 1.2〜0.12 の限度內に於ては本 滴定法に含まれる誤差の量がゴム中の亞釦の\%に無關係なる事は明かである。

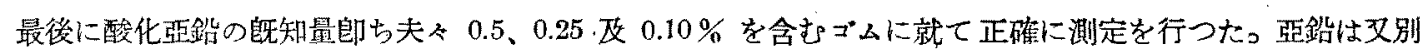

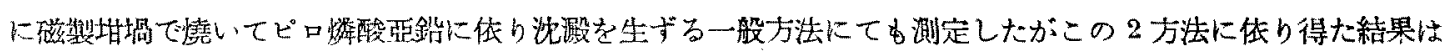
次の表にて示す。

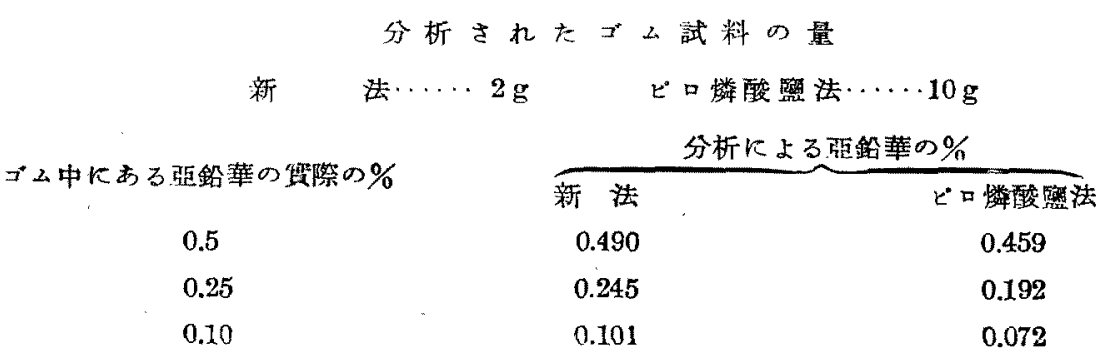

斯嵄な低率の亞鍇華にて數值を比較して見るとビロ燐酸盟法は異常に成績が落ちるに反し、新方法は珍らし くも正確な結果を與へる事が制る。この新法によつて得られる正確な結果は使用した亞鉛華が $98.5 \%$ の實祭 の酸化亞鉛を舍む事を更に考へ合せると特に注目に值する。

此の正確度に加ふるにビロ耀酸盬法の如き測定法はゴム試料を $10 \mathrm{~g}$ 使用したるも新方法は僅かに $2 \mathrm{~g}$ 要

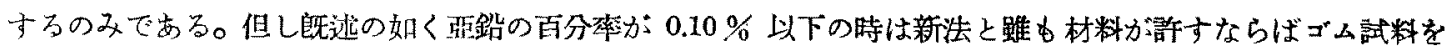
2 r でなく $5 \mathrm{~g}$ 使用するちが望李しい。大量の使用は正確度を更に增大寸る。 


\section{摘要}

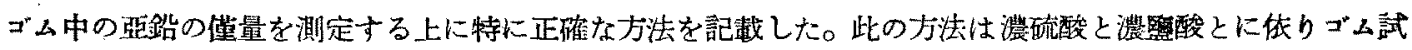

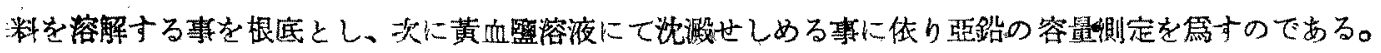

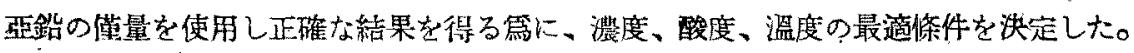

\begin{tabular}{lll}
\hline 正 & 誤 & 表 \\
\hline
\end{tabular}

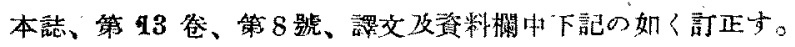

誤正

\begin{tabular}{|c|c|c|c|}
\hline 580 頁 & 下より14 行月 & 可㸊性 & 叮塑性 \\
\hline 583 頁 & 本交下上り 9 行目 & 工栄條件 & 工場候件 \\
\hline 583 頁 & 第 3 䒾下行右端 & 25 & 2.5 \\
\hline 584 頁 & 最下行 & $x \geqslant=$ & $30 \times ッ シ$ \\
\hline 586 頁 & 第 7 表右側 & プトン抽出物 & アセトン抽诎物 $(\%)$ \\
\hline 586 頁 & 第 7 表右側下行 & $(\min ) \quad 1.9$ & $(\min ) \quad 1.3 \quad 1.9$ \\
\hline 587 頁 & 本交下より 4存目 & $1 \mathrm{hr}$ & $1.5 \mathrm{hr}$ \\
\hline 590 頁 & 第 14 表中 & 重啠パラフレックス & 重質パラフルッタス \\
\hline 591 頁 & 第 15 表中 & $\begin{array}{r}\text { 伸 (\%)76.5、68.5、66.0 } \\
75.0,70.0 、 65.5\end{array}$ & $\begin{array}{r}\text { 伸(\%)765、685、660 } \\
750 、 700 、 655\end{array}$ \\
\hline 592 頁 & 上より5行日 & クロ、ホルム可滨 & "口、木九上可溶分 \\
\hline 592 貢 & 本丈下゙より5行目 & 而して $50 \%$ & 而して20\% \\
\hline 592 頁 & 下上り 3 行日 & 脫硫受 & 脫硫過度 \\
\hline 592 頁 & 川用交髇（14） & $289 ; 290(1929)$ & $289,290(1929)$ \\
\hline 593 頁 & 下より15 行目 & 1 4 0 位富 & 1-40位置 \\
\hline 593 頁 & 下より13 行目 & 1４．の位賠は勿臂 & 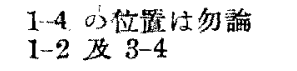 \\
\hline
\end{tabular}

